\title{
Value education and character in textbook of PAI and Character on junior high school year 2017 (analysis content, implementation and strategy)
}

\author{
Awalina Maftukhah \\ MI Ma'arif Pulutan Salatiga \\ awalinam@yahoo.com \\ DOI: $10.18326 /$ mudarrisa.v9i2.163-187
}

\begin{abstract}
The aim of this research is to know the content value and character in textbook of Islamic Religious Education and Character on Junior High School. The implementation and character in SMP Negeri 1 Salatiga, SMP Islam Al Azhar 18 Salatiga and SMP Muhammadiyah Salatiga and the teacher's strategy of character implementation in the school. This research uses a qualitative approach with a focus on values educationand characters in the handbook Islamic Religious Education. Data were analyzed by content analysis. The validity of research data is by using triangulation techniques with theory. This research also uses observative method, interview and documentation method. Based on this research, can be conclude that the content in textbook of Islamic education and character in Junior High School have 18 point and character. There are some strategy that used by teacher in SMP Negeri 1 Salatiga, SMP Islam Al Azhar 18 Salatiga and SMP Muhammadiyah Salatiga such as integrating in learning. Moreover, it's also doing by self development in school activity, prayer dhuha, Ikrar and PPK.
\end{abstract}

Keywords: Islamic education, values education, character

\section{INTRODUCTION}

Today, character education in schools is widely discussed in the context of nation's moral development. The term "manners" appears in the 
Curriculum 2013, attached to Religious Education, so that the complete sound in the curriculum structure is "Religious Education and Character". It is assumed that Religious Education has been more cognitive, so the Book of Religious Education explicitly added the word "Budi Pekerti" (Mustahdi and Sumiyarti 2014:1). The re-affirmation of "Budi Pekerti" reflects the orientation of national education which emphasizes the priority in terms of fostering the attitude, ethics and morals of the nation.

The importance of religious education as referred to in Law Number 20 Year 2003 Article 12 paragraph (1), each learner in each educational unit shall be entitled to receive religious education in accordance with his or her religion and is taught by a religious educator. Islamic Education (PAI) and Budi Pekerti fundamentally nurture morals through the habituation and practice of Islamic teachings as a whole. The curriculum of PAI and Budi Pekerti is given at SD / MI, SMP / MTs, SMA / MA and SMK / MAK levels, both of which are kokurikuler and ekstrakurikuler. PAI and Budi Pekerti are based on the Islamic aqidah on the oneness of Allah as the main source of life values for humans and the universe so as to be able to make character generation.

Junior high school students can think abstractly and internalize their potential well, can integrate what has been learned with future challenges and make future plans so as to think systematically (Desmita, 2014: 107). Religious education in junior high school is very important as a secondary education that underlies education level in high school. The 
global figures on the content of PAI and Budi Pekerti books in junior high school are important to be reviewed and mapped as follows:

Table 1.1. Curriculum of Islamic Religious Education and Budi Pekerti in junior high school

\begin{tabular}{|c|c|c|c|c|c|}
\hline Class & Aqidah Akhlak & Al-Qur'an Hadits & Tarikh & Fiqih & Nilai \\
\hline 7 & $\begin{array}{l}\text { Faith to God, honest } \\
\text { behavior, trust, } \\
\text { istiqamah, Faith to } \\
\text { the Angel, Respect } \\
\text { for parents and } \\
\text { teachers, sincere, } \\
\text { patient and forgiving }\end{array}$ & $\begin{array}{l}\text { Ar-Rahman [55]: } \\
\text { 33, Al-Mujadalah } \\
\text { [58]: } 11, \text { An-Nisa' } \\
\text { [4]: 146, Al- } \\
\text { Baqarah [2]: 153, } \\
\text { Ali Imran [3]: } 134\end{array}$ & $\begin{array}{l}\text { Prophet } \\
\text { Mohammed's } \\
\text { Prophet } \\
\text { Muhammad (s) in } \\
\text { Mecca, Hijrah to } \\
\text { Madina, Al- } \\
\text { Khulafau Ar- } \\
\text { Rashidin }\end{array}$ & $\begin{array}{l}\text { Taharah, } \\
\text { congregational } \\
\text { prayer, jum'ah } \\
\text { prayer, salat } \\
\text { jama 'and qasar }\end{array}$ & $\begin{array}{l}\text { Religious, social } \\
\text { caring, curiosity, } \\
\text { discipline, } \\
\text { responsible, } \\
\text { caring for the } \\
\text { environment, } \\
\text { rewarding } \\
\text { achievement }\end{array}$ \\
\hline 8 & $\begin{array}{l}\text { Faith in God's } \\
\text { books, humble, } \\
\text { frugal and simple }\end{array}$ & $\begin{array}{l}\text { Al-Furqan [25]: 63, } \\
\text { Al-Isra' [17]: 27, } \\
\text { Hukum bacaan Al- } \\
\text { Syamsiyah dan Al- } \\
\text { Qamariyah }\end{array}$ & $\begin{array}{l}\text { Growth of } \\
\text { Science in the } \\
\text { Umayyads and } \\
\text { Abbasids }\end{array}$ & $\begin{array}{l}\text { Prayer sunnah, } \\
\text { prostration, } \\
\text { fasting, food } \\
\text { and beverage } \\
\text { halal and haram }\end{array}$ & $\begin{array}{l}\text { Religious, } \\
\text { creative, } \\
\text { independent, } \\
\text { democratic, } \\
\text { curiosity, } \\
\text { disciplinary, } \\
\text { responsible }\end{array}$ \\
\hline 9 & $\begin{array}{l}\text { Faith to the last day, } \\
\text { faith in Qada and } \\
\text { Qadar, tolerance, } \\
\text { obedience to parents } \\
\text { and teachers }\end{array}$ & $\begin{array}{l}\text { Az-Zumar [39]: 53, } \\
\text { An-Najm [53]: 39- } \\
\text { 42, Ali Imran [3]: } \\
\text { 159, } \\
\text { Al-Hujurat [49]: } 13\end{array}$ & $\begin{array}{l}\text { The presence of } \\
\text { Islam in the } \\
\text { archipelago and } \\
\text { Islamic tradition } \\
\text { in the archipelago }\end{array}$ & $\begin{array}{l}\text { Akikah and } \\
\text { sacrifices, zakat, } \\
\text { hajj and umrah }\end{array}$ & $\begin{array}{l}\text { Religious, } \\
\text { tolerant, } \\
\text { democratic, } \\
\text { curiosity, peace, } \\
\text { social caring, } \\
\text { reading, } \\
\text { discipline }\end{array}$ \\
\hline
\end{tabular}

Content of this curriculum is very interesting if adjusted the personality conditions of junior high school students are diverse. Students tend to want to try new things and find identity, even adolescence shows the nature of the transition period (F.J. Monks, et al, 1992: 253), so easily affected with the surrounding environment. It is important for students to understand their religious knowledge and actualize it in concrete actions and daily attitudes appropriate to their religious demands, both in the form of ritual worship and social worship. The ideal picture for the debriefing of moral and character of junior high school students can be explored from the book of Religious Education and Character. The 
authors are interested in raising the importance of value education and junior high level character. This study examines Islamic Religious Education at junior level. The research will be identified as follows: 1) Content (content) values and characters listed in the book PAI and Budi Pekerti, 2) Implementation of values and character education at junior level, 3) PAI teacher strategy in instilling values and character.

The authors limit the location of research that is in SMP Negeri 1 Salatiga as the favorite SMP Negeri in Salatiga. SMP Islam Al-Azhar 18 Salatiga as a private junior under the auspices of the Educational Foundation characterized by Islam and SMP Muhammadiyah Salatiga as private educational institutions under the umbrella of community organizations (Muhammadiyah) in 2017. The author is interested to examine these three schools by analyzing the PAI on the aspects of values and characters. Each school has a distinctive feature of underdeveloped subjects, has different status and background so it is possible that implementation is also different from the advantages of each program.

As far as the author's observations, there have been several reviewers who conducted research on character formation. First, qualitative research conducted by Zuhriyah about character formation for junior high school students. The result of the research stated that the formation of independent character of the students is in the medium category. Among the values of the developed characters are instilling the value of monotheism, instilling manners, instilling confidence, instilling a 
sense of togetherness, instilling a sense of responsibility, instilling students' creative attitude (Zuhriyah, 2012: xvi).

Secondly, Latifa Annum's research shows that the implementation of character education in SMP Muhammadiyah Palangkaraya is done through routine activities, exemplary, and conditioning. Implemented character values are still less successful in achieving predefined indicators (Latifa Annum Dalimunthe, 2013: ix). Third, research Darmiyati Zuhdi, et al that comprehensive character education integrated in learning Indonesian, Science and IPS in elementary school (MI / SD) and development of a conducive school culture (Darmiyati Zuhdi, 2010: 110).

Anik Ghufron research, Integration of Nation Character Values on Learning Activities undertaken at stages: introduction, core and cover (Anik Ghufron, 2010:13-23). Here to note is that each stage of learning needs to have a portion of time for the actualization of the nation's character values as contained in the formulation of competence. Therefore, the requirement for the school, teachers, parents and students to realize the learning activities contained character values so that graduates of the school are able to master the competence as well as carry out actions that are the embodiment of the nation's character values, as desired by the community.

Almuntaqo Zainuddin, focusing on the values of character education in the book of Islamic Education of Elementary Class I-VI published by Tiga Serangkai (Almuntaqo Zainuddin, 2016: 234-240). 
The research findings show that the subjectivity of author of PAI SD book determines the character education values so that: 1) the learning of 18 character values has not been achieved; 2) explanation of character education values does not increase according to class level; 3) the authors' inadequacy leads to an explanation of improper characters; 4) the existence of another character value that is not mentioned source.

From several studies that the authors described above, it has discussed several issues related to character education in learning activities and integrated in several subjects. The author intends to analyze the value and Character education in the book of Islamic Religious Education in detail to criticize the book's content. No studies have yet to discuss specifically on values and character education in the curriculum of Islamic Religious Education and Budi Pekerti in junior high school level.

Values are an ideal, a paradigm that expresses the desired and respected social realities. Essentially values are beliefs that an idealized way of life is the best way for society. Since values are trustworthy values function to inspire members of society to behave in a way that their society accepts. Because values are ideal images, they are a tool for determining the quality of one's behavior (Ralp H. Gabriel, 1991: 144). Value education essentially gives two main essences as its target that is divinity value and humanity value. The divine value is the value that becomes the basis in man as a religious 
being. While the value of humanity related to human interaction as a social creature. Both of these values are applied in behavior, ethics, morals, aesthetics (Ridhahani, 2013: 17).

Character education for the present is given a broader meaning. Character education does not merely teach what is right and what is wrong, more than that character education inculcates habituation about good things so learners become (cognitive domain) about which is right and wrong, able to feel (affective domain) value good and commonly do it (psychomotor domain). Character education relates to habit that is continuously practiced or done (Daryanto and Suryatri Darmiatun, 2013: 47). Character education referred to in this research is the accumulation of various values and characters contained in Islamic religious subjects in junior high school to form a personality through character education, the results seen in action.

\section{METHODOLOGY}

The approach used by researchers is a qualitative approach. The type of this research is qualitative research with content analysis method, observation method, interview and documentation. To know the content of value education and character in the book PAI and Budi Pekerti junior level with content analysis method. This study focuses on the analysis or interpretation of written materials based on the context. 
In this research primary data source is PAI and Budi Pekerti junior high level. Key informants are PAI Junior High School teachers in Salatiga for further exploration of values and character education in PAI and Budi Pekerti books at junior high school level. This observation is used to directly observe the character education management in Salatiga Junior High School covering the implementation of learning and planting the value of character education in the classroom conducted by the teacher to the students.

Interviews were addressed to PAI teachers at the Junior High School level in Salatiga to obtain information on implementation and values and character building strategies in PAI and Budi Pekerti books in schools. Interviews were also conducted to obtain information related to character education management. Documentation as a complement to the use of interview methods. Observation of school documents in the form of planning documents, organizational structure of schools, reports of observation and evaluation of the implementation of character education. In this study researchers documented: 1) the form of planting values and character of junior high school in Salatiga through religious slogans, educate and give motivation, 2) activity of researcher interview to organizational structure in order to obtain information and data related to character education management.

Data analysis is done through the process of searching and arranging systematically data obtained from interviews, observation and documentation. The collected data is then analyzed by qualitative 
descriptive method. The steps taken are: First, that is finding the values of education and character set Central Curriculum. Second, make a classification based on existing data on the content of books PAI and Budi Pekerti SMP. Third, conduct an analysis based on indicators. Data analysis activities are data reduction (selecting important data, as well as creating categories), display data (presenting data into patterns), and conclusion drawing / verification (drawing conclusions and verification). The validity of data of research result using data triangulation technique.

\section{DISCUSSION}

\section{CONTENT VALUE AND CHARACTER}

Education value direction is the inculcation of certain values on the subject students. Summaries of various values form individual characters. In the language of society is easier and not debatable just mention character education. The accumulation of the values will form the characters. Education in the 2013 curriculum refers to character education. Values education is an educational program that organizes and "simplifies" moral resources and is presented with due regard to psychological considerations for educational purposes (Nurul Zuriyah, 2008: 22). Character education is character education that involves aspects of knowledge (cognitive), feeling (feeling) and action (action) (Hamdani Hamid, 2013: 33). The difference can be seen in the following table: 
Table 1. Differences in Values and Character

\begin{tabular}{lll}
\hline \multicolumn{1}{c}{ Difference } & \multicolumn{1}{c}{ Values } & \multicolumn{1}{c}{ Character } \\
\hline Source / Reference & $\begin{array}{l}\text { Values are something that is } \\
\text { considered good and right } \\
\text { according to one's belief. }\end{array}$ & $\begin{array}{l}\text { Character is the values of } \\
\text { universal human behavior } \\
\text { covering all human activity. }\end{array}$ \\
\hline Nature of Thought & $\begin{array}{l}\text { Empirical. } \\
\text { The process of the } \\
\text { appearance of deeds }\end{array}$ & $\begin{array}{l}\text { Appears because of the combination of reason, } \\
\text { atmosphere }\end{array}$ \\
\hline
\end{tabular}

Values (characters) and characters are descriptions of the various basic behaviors and attitudes that learners expect for junior high school/ MTs as the basis of their personal formation (Nurul Zuriyah, 2011: 217-219).

In terms of components, character education in the view of Thomas Lickona emphasizes the importance of three components of good character (components of good character) that is moral knowing or knowledge of moral, moral feeling or feelings about moral and moral action or moral deeds. Character education values developed by the Ministry of Education (Curriculum Center Ministry of National Education, 2009: 9-10) there are 18 characters. These values are derived from religion, pancasila, culture, and national education goals. The eighteen values are: religious, honest, tolerance, discipline, hard work, creative, independent, democratic, curiosity, spirit of nationality, love of the homeland, appreciate achievement, friendly / communicative, peace loving, love to read, , social care, and responsibility.

The relationship between character education with Islamic education and character can be seen in two sides, namely the material and 
the learning process. In general, the material aspect submitted in junior high school is Al-Quran Hadith, Akhlak, Fiqh, Tarikh and Islamic Culture. But there is a development of material in each school as follows:

Figure 1.1. Development of Islamic Religious Education Material
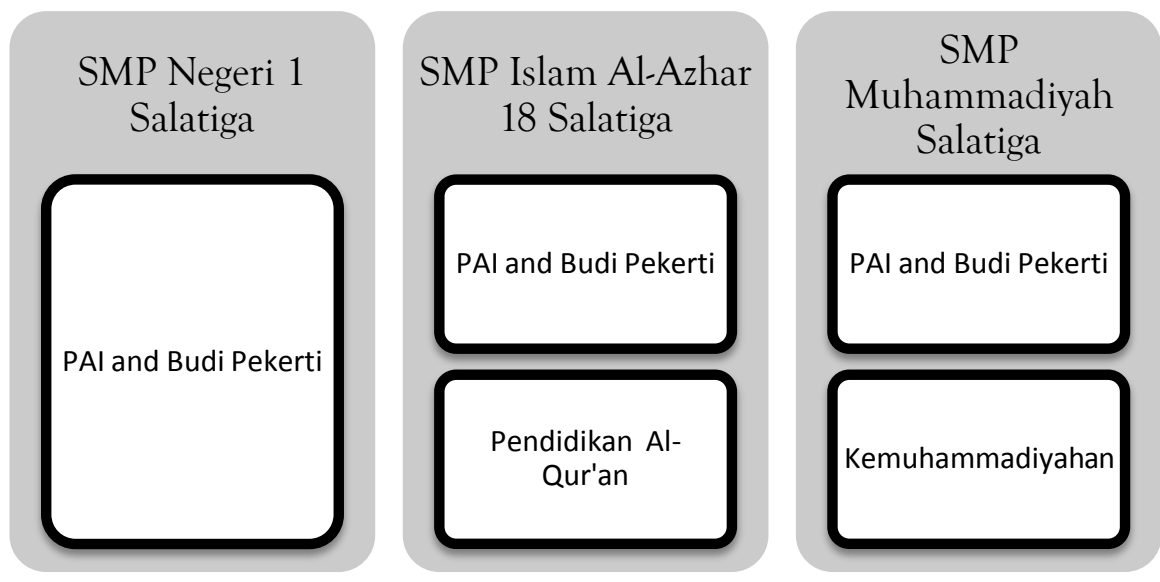

In terms of material, Education of Islam and Budi Pekerti can cover the education of value and character. This can be identified in the table 2 :

Table 2. Values and characters in PAI \& Character textbook grade VII

\begin{tabular}{ll}
\hline \multicolumn{1}{c}{ Aspect } & \multicolumn{1}{c}{ Value and Character } \\
\hline $\begin{array}{l}\text { Al-Quran Hadith } \\
\text { (The Qur'ani verses on Islam and Science in }\end{array}$ & $\begin{array}{l}\text { Religius, honest, tolerance, discipline, hard } \\
\text { work, creative, independent, democratic, }\end{array}$ \\
$\begin{array}{l}\text { QS. Ar-Rahman [55]: 33, Al-Mujadalah [58]: } \\
\text { curiosity, spirit of nationality, love the } \\
\text { 11, An-Nisa' [4]: 146, Al-Baqarah [2]: 153, } \\
\text { homeland, appreciate achievement, friendly/ } \\
\text { Ali Imran [3]: 134 and related hadith, Law } \\
\text { communicative, love peace, like to read, } \\
\text { environmental care, Social care, responsible }\end{array}$ \\
\hline $\begin{array}{l}\text { Aqidah Sukun/ Tanwin Reading) } \\
\text { (Believe in Allah through Asmaul Husna, }\end{array}$ & $\begin{array}{l}\text { Religius, honest, tolerance, discipline, hard } \\
\text { work, independent, curiosity, friendly/ } \\
\text { Faith to the Angel) }\end{array}$ \\
\hline $\begin{array}{l}\text { Morals } \\
\text { (Commendable Behavior, Calm Life with }\end{array}$ & $\begin{array}{l}\text { Religious, honest, tolerant, disciplined, } \\
\text { rewarding achievement, friendly/ } \\
\text { Honesty, Amanah, and Istiqamah, Respect } \\
\text { communicative, peace loving, caring } \\
\text { for parents and teachers, Behavior Ikhlas, } \\
\text { Patience and forgiveness) }\end{array}$ \\
\hline
\end{tabular}




\section{Mudarrisa: Jurnal Kajian Pendidikan Islam, Vol. 9, No. 2, 2017}

\section{Fiqh}

(Thaharah, Beautiful Togetherness with Congregational Prayer, Fostering Sense of Unity with Praying Friday, Ease of Islam through Jamaat Salat 'and Qasar)

Tarikh and Islamic Culture (Chronology of Birth to Period)

Adult, Prophet Muhammad's Appointment as Prophet / Prophet, Prophet Muhammad's Prophet Muhammad (s) in Mecca, Hijra to Madinah, Al-Khulafau Ar-Rashidin Successor of the Prophet Muhammad's Struggle)
Religious, honest, tolerant, disciplined, hard work, creative, independent, spirit of nationality, love homeland, friendly/ communicative, love reading, care environment, responsibility

Religious, honest, tolerant, disciplined, hard work, creative, independent, democratic, curiosity, spirit of nationality, love of the homeland, appreciate achievement, friendly/ communicative, love peace, love reading, caring environment,

Table 3. Values and characters in PAI \& Character textbook grade VIII

\begin{tabular}{|c|c|}
\hline Aspect & Value and Character \\
\hline $\begin{array}{l}\text { Al-Quran Hadith } \\
\text { (The verses of the Qur'an about Humble, } \\
\text { Thrifty, and Simple in the Sura of Al- } \\
\text { Furqan [25]: 63, Al-Isra '[17]: 27, The Law } \\
\text { of Recitation of Al-Shamsiyah and Al- } \\
\text { Qamariyah) }\end{array}$ & $\begin{array}{l}\text { Religious, honest, tolerant, disciplined, hard } \\
\text { work, creative, independent, curiosity, } \\
\text { respectful achievement, friendly/ } \\
\text { communicative, reading, caring environment, } \\
\text { social care, responsibility }\end{array}$ \\
\hline $\begin{array}{l}\text { Aqidah } \\
\text { (Faith in the Books of God) }\end{array}$ & $\begin{array}{l}\text { Religious, honest, tolerant, curiosity, } \\
\text { friendly/communicative, avid read, caring } \\
\text { environment, social care, responsibility }\end{array}$ \\
\hline $\begin{array}{l}\text { Morals } \\
\text { (Exemplifies the Glory and Honesty of } \\
\text { Allah's Apostles, Healthy Living with Halal } \\
\text { and Nutritious Foods and Beverages, } \\
\text { Avoiding Alcoholic Drinks, Gambling, and } \\
\text { Fighting) }\end{array}$ & $\begin{array}{l}\text { Religious, honest, tolerant, disciplined, hard } \\
\text { work, creative, independent, democratic, } \\
\text { respectful } \\
\text { friendly/communicative, love peace, love } \\
\text { reading, caring environment, social care, } \\
\text { responsibility }\end{array}$ \\
\hline $\begin{array}{l}\text { Jurisprudence } \\
\text { (Practicing Salat Sunnah, Sujud, Fasting, } \\
\text { Eating Halal Food and Drinking Away } \\
\text { from the Haram) }\end{array}$ & $\begin{array}{l}\text { Religious, honest, tolerance, discipline, } \\
\text { curiosity, spirit of nationality, love of the } \\
\text { homeland, friendship/communicative, social } \\
\text { care, responsibility }\end{array}$ \\
\hline $\begin{array}{l}\text { Tarikh and Islamic Culture (Growth of } \\
\text { Science in the Umayyad Period, Growth of } \\
\text { Science in the Abbasid Period) }\end{array}$ & $\begin{array}{l}\text { Religious, tolerance, discipline, hard work, } \\
\text { curiosity, spirit of nationality, love of the } \\
\text { homeland, respect for achievement, friendly } \\
\text { /communicative, love peace, love reading, } \\
\text { caring environment, social care, responsibility }\end{array}$ \\
\hline
\end{tabular}




\section{Mudarrisa: Jurnal Kajian Pendidikan Islam, Vol. 9, №. 2, 2017}

Table 4. Values and characters in PAI \& Character textbook grade IX

\begin{tabular}{|c|c|}
\hline Aspect & Value and Character \\
\hline $\begin{array}{l}\text { Al-Quran Hadith } \\
\text { (Al-Qur'an verses on Optimism, Ikhtiar, and } \\
\text { Tawakal attitudes, in Surah Az-Zumar [39]: } \\
\text { 53, An-Najm [53]: 39-42, Ali Imran [3]: 159, } \\
\text { Tolerance and Appreciate the Difference in } \\
\text { QS Al-Hujurat [49]: 13, Understanding } \\
\text { Tajwid on Tafkhim and Tarqiq }\end{array}$ & $\begin{array}{l}\text { Religious, tolerance, discipline, hard work, } \\
\text { democratic, curiosity, spirit of nationality, } \\
\text { love of the homeland, appreciate } \\
\text { achievement, love to read, care } \\
\text { environment, social care }\end{array}$ \\
\hline $\begin{array}{l}\text { Aqidah } \\
\text { (Faith to the Last Day, Faith to Qada 'and } \\
\text { Qadar) }\end{array}$ & $\begin{array}{l}\text { Religious, honest, disciplined, curiosity, } \\
\text { fond of reading, caring for the environment, } \\
\text { social care, responsibility }\end{array}$ \\
\hline $\begin{array}{l}\text { Morals } \\
\text { (Optimistic Attitude, Attempt, and } \\
\text { Challenge, Honest Attitudes, Grace, and } \\
\text { Shame, Tolerance, Honor and Obedience to } \\
\text { Parents and Teachers) }\end{array}$ & $\begin{array}{l}\text { Religious, honest, tolerant, disciplined, } \\
\text { democratic, curiosity, spirit of nationality, } \\
\text { love of the homeland, respect for } \\
\text { achievement, peace of mind, caring for the } \\
\text { environment, }\end{array}$ \\
\hline $\begin{array}{l}\text { Jurisprudence } \\
\text { (Akikah and Kurban, Hajj and Umrah) }\end{array}$ & $\begin{array}{l}\text { Religious, disciplined, hard work, creative, } \\
\text { independent, curiosity, spirit of nationality, } \\
\text { love of the homeland, } \\
\text { friendly/communicative, caring } \\
\text { environment, social care, responsibility }\end{array}$ \\
\hline $\begin{array}{l}\text { Tarikh and Islamic Culture (Islamic } \\
\text { Presence of Reconciling the Earth of the } \\
\text { Archipelago, Tracing the Islamic Tradition } \\
\text { in the Archipelago) }\end{array}$ & $\begin{array}{l}\text { Religious, tolerance, discipline, hard work, } \\
\text { democratic, curiosity, spirit of nationality, } \\
\text { love of the homeland, appreciate } \\
\text { achievement, love to read, care } \\
\text { environment, social care }\end{array}$ \\
\hline
\end{tabular}

The content of value education and special characters in SMP

Muhammadiyah in Subject Kemuhammadiyahan as follows:

Table 5. Values and Characters in the curriculum Kemuhammadiyahan

Kemuhammadiyahan
$\begin{aligned} & \text { Understanding and history of the Religious, curiosity, respect for diversity, } \\ & \text { establishment of Muhammadiyah, cooperation, tolerance, discipline, hard work, } \\ & \text { autonomous organizations and the role of democratic, curiosity, reading, environmental } \\ & \text { Muhammadiyah students, Matan beliefs care, social care } \\ & \text { and aspirations of Muhammadiyah life, } \\ & \text { recognize the attributes of Muhammadiyah }\end{aligned}$




\begin{tabular}{|c|c|}
\hline $\begin{array}{l}\text { Khittah Perjuangan Muhammadiyah, } \\
\text { Muhammadiyah's personality values, } \\
\text { challenges and obstacles of Muhammadiyah }\end{array}$ & $\begin{array}{l}\text { Religious, respect diversity, cooperation, hard } \\
\text { work, tolerance, discipline, hard work, } \\
\text { democratic, curiosity, spirit of nationality, love } \\
\text { of the homeland, appreciate achievement, love } \\
\text { reading, environmental care, social care }\end{array}$ \\
\hline $\begin{array}{l}\text { The position of human beings as the } \\
\text { monotheistic creatures of God, the } \\
\text { obligation of humans as individuals who } \\
\text { have the rights and potential to develop, } \\
\text { the responsibility of Muslim man in the life } \\
\text { of society }\end{array}$ & $\begin{array}{l}\text { Religious, tolerant, disciplined spirit of } \\
\text { nationality, love of the homeland, appreciate } \\
\text { achievement, love reading, caring environment, } \\
\text { social care, hard work, democratic, curiosity }\end{array}$ \\
\hline
\end{tabular}

While in the learning process, teachers in teaching Islamic Religious Education to learners contain values and character education. In fact, teachers in the implementation of value and character education began since the teacher made a lesson plan.

\section{IMPLEMENTATION OF CHARACTER EDUCATION}

Implementation of Character Education in PAI subjects in SMP Negeri 1 Salatiga uses two ways, namely intrakurikuler and ekstrakurikuler. The implementation of Value Education and character in PAI subjects is to include eighteen character values in all PAI learning materials. Implementation of education Values and characters performed by teachers have been included in the RPP made. The material developed by the teacher is done through the activities of habituation "Saturday Religion", dhikr, reading of asmaul husna and prayer, religious lecture, and also material development especially moral content. The form of implementation of education Values and characters in the school is done in every learning and proclaimed routine activities eg "Movement Limut" 
(Five minute Movement pick up) as a form of embodiment of Islamic teachings on cleanliness.

Implementation of character education in Islamic Junior High School Al-Azhar 18 Salatiga is done by Model Scientific Approach, Discovery, Inquiry. Programs that are featured as a form of student values and character are Tahfidz Program, Friday Blessings, Friday Prayers, AlWaqi'ah Memory Day one verse, Pledge for Consolidation of aqidah everyday, Kultum, Lagu Indonesia Raya and flag ceremony activities every 17 th, as well as National day commemoration.

Figure 1. Integration of Values and Character Education

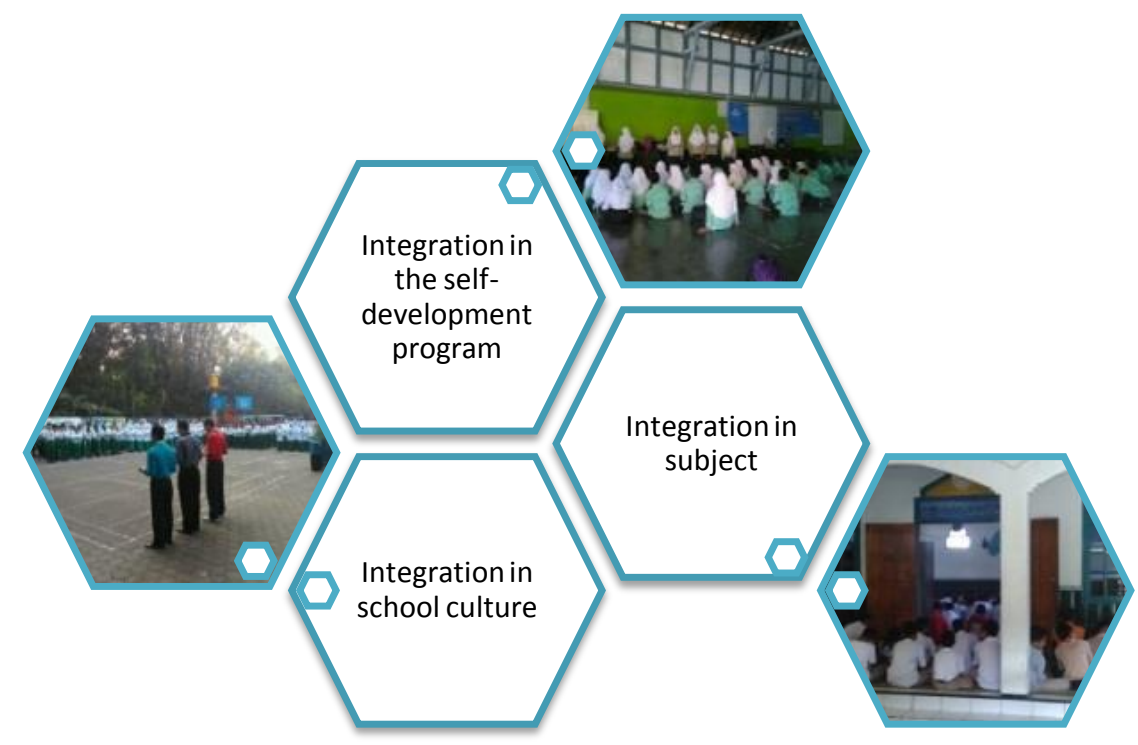

\section{Integration in the self-development program}

The planning and implementation of character education in selfdevelopment programs, can be done through integration into daily activities in the school, through regular school activities, spontaneous 
activities, exemplary, conditioning, co-curricular activities or extracurricular activities, and daily activities at home and in society.

School routine activities

Routine activities are routine or regular activities performed at any time. Routine activities can also mean activities that students do continuously and consistently at all times. Some examples of routine activities include Monday ceremonies, state grand ceremonies, body hygiene checks, class pickets, praying in congregations, marching in class, praying before classes begin and ending, and greeting teachers, educators and friends.

Spontaneous activity

Spontaneous activity may also be called incidental activity. This activity is done spontaneously without planning first. This activity is done when the teacher knows the learner to take the action that is less praiseworthy and must be corrected at that time also so that learners do not repeat it on another occasion. For example, when there is a learner who throws garbage carelessly, then at that moment the teacher knows must immediately provide corrections so that learners can throw the garbage in place. This spontaneous activity applies not only to the less-than-learned behaviors of the learner, but also to the commendable behavior or positive behavior of the learners. Spontaneous response, when learners do positive behavior, is expected to make learners feel happy and proud so that any positive behavior that can be deeply rooted in him. For example, when there is a learner helping his fallen friend, the teacher should immediately praise his or her actions. 
Example

Exemplary is the attitude of "being an example". Attitude to be an example is the behavior and attitude of teachers and education personnel and students in providing examples through good actions so that it is expected to be role models for other students. Examples of this activity for example a teacher to be a clean, neat, friendly, and easy personal example.

Conditioning

Conditioning relates to the efforts of schools to organize the physical and non-physical environment in order to create an atmosphere to support the implementation of character education. The activities of organizing the physical environment, for example, are conditioning clean toilets, garbage cans, green pages with trees, wise words poster on display in school hallways and in classrooms. While non-physical environmental conditioning is managing conflict between teachers so as not to lead to division, or even eliminate the conflict.

Co-curricular activities and or extracurricular activities

Co-curricular and extra-curricular activities are activities outside of the learning activities. Although outside of the learning activities, teachers can also integrate them in learning. These activities have actually supported the implementation of character education. However, good planning, implementation and evaluation or revitalization of such co-curricular and extra-curricular activities are required in order to carry out character education for students.

Daily activities at home and in the community 
This activity is a support activity of character education in school. home (family) and the community is an important partner of successful implementation of character education in schools. the implementation of character education as well as anything, if not supported by family and community environment will be in vain. In this activity, schools can seek to create harmony between the character developed in school with the homes and the public.

\section{Integration in subject}

The development of the values of cultural education and the character of the nation is integrated in every subject of each subject. These values are included in the syllabus and RPP (Learning Implementation Plan). The development of the values themselves in the syllabi is pursued through the following ways: (1) examine the Competency Standards (SK) and Basic Competencies (KD) on the Content Standards (SI) to determine whether the cultural values and character of the listed nation are already covered in it, (2) using a table showing the relationship between SK and KD with values and indicators to determine the value to be developed, (3) listing the character values in the table into syllabus and lesson plan, (4) developing participant learning process actively enabling learners to have opportunities to internalize values and demonstrate them in appropriate behaviors, and (6) provide assistance to learners, whether they have difficulty in internalising values or to demonstrate in behavior. Character Education Planning in PAI is done during the preparation of lesson 
planning. Preparation of lesson plans in the form of syllabus making and learning implementation plan (RPP). Based on syllabus and syllabus documents, character education in PAI includes the values of Character Education by looking at SK.

\section{Integration in school culture}

School culture is a pattern of values, norms, attitudes, and habits that are formed in the long journey of a school where the school is held together by all the citizens of the school, as their basis in understanding and enlightening the problems that arise in school. So school culture is the atmosphere of school life where learners interact, both learners with each other, teachers with teachers, administrative staff with each other, and between members of school community groups. The internal interactions of groups and between groups are bound by some common rules, norms, morals, and ethics applicable in a school. Leadership, exemplaryness, friendliness, tolerance, hard work, discipline, social concern, environmental concern, pride, and responsibility are values developed within the school culture. The development of values of character education in school cultures includes activities by principals, teachers, administrative staff when communicating with learners and using school facilities. The development of the character's values can occur either in class, school, or outside school.

Class, through the learning process of each subject or activity designed in such a way. Each learning activity develops cognitive, affective, 
and psychomotor abilities. Therefore it is not always necessary for special learning activities to develop values on cultural education and character of the nation. In addition, in developing values such as honest, hard work through the usual learning activities of teachers. But sometimes teachers need an effort to create a condition so that learners can apply certain values, such as environmental care or social care.

Schools, through various school activities that all school members attend, are planned from the outset, included in the calendar. The cultivation of values and character in SMP Muhammadiyah Salatiga is integrated in the learning activities in the classroom and outside the classroom. In addition to the learning of special feature materials packaged in the lessons of kemuhammadiyahan also takes seriously the formation programs of the characters, as well as the following programs: 1) PesantrenRamadhan, 2) Keputrian (Women's Special Study of Islam). 3) Dhuha Prayer and Jum'at Berjama'ah. 4) Read Write the Qur'an under the guidance of teachers and peer tutors. (5) Tilawatil Qur'an. 6) Rote and Practice Worship. 7) Visiting friends of Sick and Takziyah. 9) Friday Infaq. The model of integrating character education in three junior high schools was conducted in several ways, namely integration in self-development programs, in subjects, and in school culture.

\section{STRATEGY OF VALUE AND CHARACTER}

Education is the backbone of the nation's character building strategy. This happens because in the macro context, the organization of character 


\section{Mudarrisa: Jurnal Kajian Pendidikan Islam, Vol. 9, No. 2, 2017}

education includes the overall planning, organizing, implementing and quality control activities that involve all the main units within the national education stakeholders. In macro character development is divided into three stages, namely planning, implementation and evaluation of results.

At the planning stage a character device was developed that was unearthed, crystallized and formulated using various philosophical, theoretical and empirical sources. At the implementation stage, it is developed learning experience and the process of learning that leads to the formation of character in the students through intervention and habituation. The description of values and character education in PAI and Budi Pekerti curriculum for religious values in SMP Muhammadiyah Salatiga are: before classroom learning begins, learners make prayers together, read asmaul husna, and memorize al-Quran related to matter; in the first rest period, teachers encourage students to perform the prayers dhuha, while at the second break time, students are expected to perform the prayers dzuhur congregation.

Based on the results of observations of researchers at SMP Negeri 1 Salatiga, SMP Al-Azhar 18 Salatiga and SMP Muhammadiyah Salatiga, the researcher has a tentative conclusion that SMP Negeri 1 Salatiga, SMP AlAzhar 18 Salatiga and SMP Muhammadiyah Salatiga are educational institutions that have implemented character education programs. Seen from the habits that inculcate the values of character education conducted in schools, such as: 1) the habituation of pronunciation greetings when meeting father/ mother teacher and friends, 2) shake hands/ shake hands 
when new to school and when going home, 3) Praying in dhuha and dhuhur, 4) recitation of recitation of the Quran, 5) Friday alms.

Figure 2. Value Planting
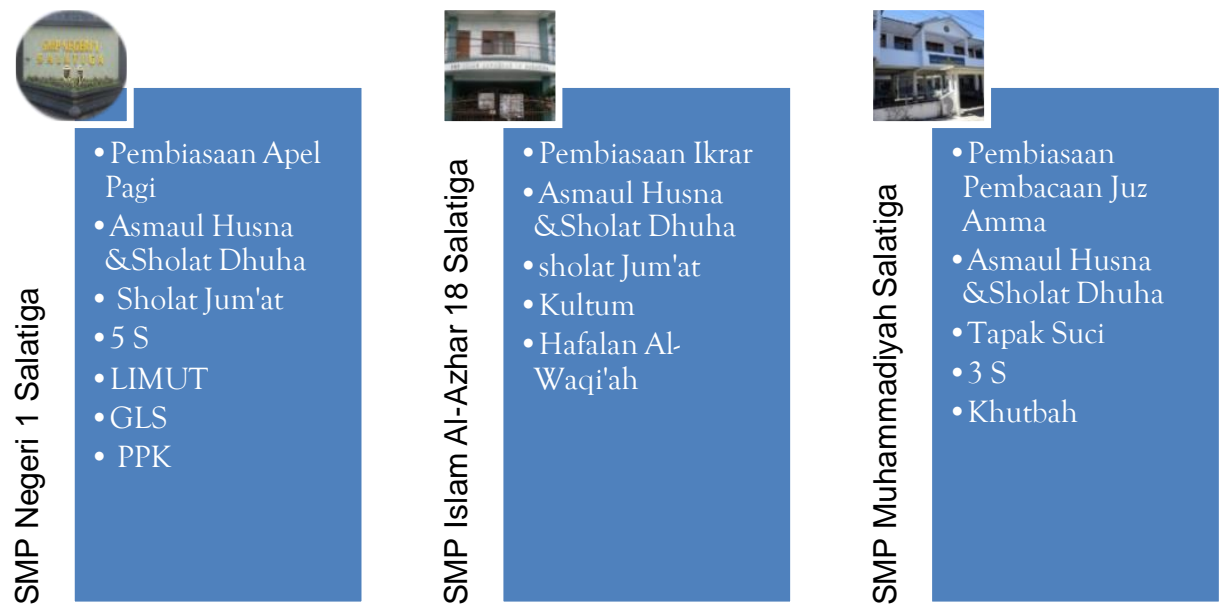

The exposure to the above habits indicates that the school is a school that actually implements character education, characterized by some activities that can foster good character in the learner. Based on the fact, many parents who want their children to go to school with the aim that their children not only intellectual smart but also smart moral, in other words want his son has a good character. The strategy of planting value and character that is by using model Scientific approach, Discovery, Inquiry, Problem based learning. The use of values and character building strategies is tailored to the material taught by the teacher.

From this reality, it shows the successful implementation of Character Education in PAI in junior high school. This success can not be separated from the supporting factors, namely complete infrastructure 
facilities; there is support from the principal, parents and cohesiveness of teachers. As for the factors inhibiting the planting of values and character of the students that there are some teachers who are less consistent to remind children in school activities.

\section{CONCLUSION}

Based on the results of the research can be concluded that the values of education and character in the book "Islamic Education and Character Budi" includes 18 values and characters, namely religious, honest, tolerance, discipline, hard work, creative, independent, democratic, curiosity, nationality, homeland love, respect for achievement, friendship/ communicative, peace loving, reading, caring, environment, social responsibility, responsibility.

In its implementation, Character Educations in Islamic Education and Budi Pekerti have higher intensity, including in learning planning. There is addition in coaching and higher intensity. The details of character education implementation in PAI in SMP Negeri 1 Salatiga, Islamic Junior High School Al-Azhar 18 Salatiga and SMP Muhammadiyah Salatiga are as follows: 1) Character education policy in PAI SMP in Salatiga through three ways, subjects, self-development, and culture school; 2) Character education planning in PAI is done when preparing lesson planning. Preparation of lesson plans in the form of syllabus and lesson plan implementation; 3) Evaluation of the implementation Character 
education in PAI includes: input (input), process (process), output (outcome), and outcomes (impact).

The strategy used by teachers in instilling values and character education is by integrating in all learning activities. It is also done through intrakurikuler activities, extra curricular, habituation, and school culture. Commitment, communication and togetherness with various parties need to be improved in the process of implementing the values of the character of the students, especially between teachers and parents so that the planting of character values in the family environment is in line with the implementation process of character education in schools. Educational authorities should mencanagkan special program of planting values and character in school. Where students can spread positive characters to other students (moral action).

\section{References}

Dalimunthe, L. A. (2013). "Pendidikan Karakter di Sekolah Menengah Pertama Muhammadiyah Palangkaraya”, Tesis, IAIN Antasari.

Daryanto \& Suryatri Darmiatun. (2013). Implementasi Pendidikan Karakter di Sekolah. Yogyakarta: Gava Media.

Desmita. (2014). Psikologi Perkembangan Peserta Didik. Bandung: PT Remaja Rosdakarya.

Ghufron, A. (2010). "Integrasi Nilai-Nilai Karakter Bangsa pada Kegiatan Pembelajaran”, Cakrawala Pendidikan, 13-23.

Hamid, H. (2013). Pendidikan Karakter Perspektif Islam. Bandung: Pustaka Setia.

Ilahi, M. T. (2014). Gagalnya Pendidikan Karakter: Analisis dan Solusi Pengendalian Karakter Emas Anak Didik. Yogyakarta: Ar-Ruzz Media. 
Lickona, T. (2013). Character Matters: Persoalan Karakter Bagaimana Membantu Anak Mengembangkan Penilaian yang Baik, Integritas, dan Kebajikan Penting lainnya.Terjemahan. Juma Abdu Wamaungo dan Jean Antunes Rudolf Zien, Jakarta: Bumi Aksara.

Lickona, T. (2013). Pendidikan Karakter: Panduan Lengkap Mendidik Siswa Menjadi Pintar dan Baik. Terjemahan Lita S. Bandung: Nusa Media. Muhammad Ahsan \& Sumiyati. (2015). Pendidikan Agama Islam dan Budi Pekerti Kelas IX SMP/MTs. Jakarta: Kementerian Pendidikan dan Kebudayaan.

Muhammad Ahsan \& Sumiyati. (2014). Pendidikan Agama Islam dan Budi Pekerti Kelas VIII SMP/MTs.Jakarta: Kementerian Pendidikan dan Kebudayaan.

Mustahdi \& Sumiyati. (2014). Pendidikan Agama Islam dan Budi Pekerti Kelas VII SMP/MTs.Jakarta: Kementerian Pendidikan dan Kebudayaan.

Ridhahani. (2013). Transformasi Nilai-nilai Karakter/Akhlak dalam Proses Pembelajaran. Yogyakarta: Lkis.

Samani, M \& Hariyanto. (2014). Konsep dan Model Pendidikan Karakter. Bandung: PT. Remaja Rosdakarya.

Seshadri. (2005). "An Approach to Value Orientation of Teachers' Education", Journal of Value Education, 9-17.

Silay, N. "A Survey of Values Education and its Connection with Character Education", Academy Journal of Interdiciplinary Studies (2013): 131-138.

Zuchdi, D. (ed). (2011). Pendidikan Karakter dalam Perspektif Teori dan Praktik Yogyakarta: UNY Press.

Zuhriyah, N. (2008). Pendidikan Moral dan Budi Pekerti dalam Perspektif Perubahan. Jakarta: Bumi Aksara. 